\title{
Condensation Reactions of Benzaldehyde Catalysed by Gold Alkoxides
}

\author{
Sanshiro Komiya, Takuo Sone, Yoko Usui, Masafumi Hirano and Atsushi Fukuoka \\ Depariment of Applied Chemistry, Faculty of Technology, Tokyo University of Agriculture and Technology, \\ 2-14-16 Nakacho, Koganei, Tokyo 184, Japan
}

\begin{abstract}
Condensation reactions between active methylene compounds, $\mathrm{CH}_{2}(\mathrm{X})(\mathrm{Y})$, such as alkyl cyanoacetate or acetophenone and benzaldehyde proceed smoothly in the presence of catalytic amounts of gold alkoxides, $\mathrm{Au}(\mathrm{OR}) \mathrm{L}\left(\mathrm{L}=\mathrm{PPh}_{3}: \mathrm{R}=\mathrm{CH}_{2} \mathrm{CF}_{3}(1 \mathrm{a}), \mathrm{CH}\left(\mathrm{CF}_{3}\right)_{2}(\mathbf{1 b}) ; \mathrm{L}=\mathrm{PC}_{3}: \mathrm{R}=\mathrm{CH}_{2} \mathrm{CF}_{3}(\mathbf{1 c}), \mathrm{CH}\left(\mathrm{CF}_{3}\right)_{2}(1 \mathrm{~d})\right.$ or AuMe $_{2}(\mathrm{OR}) \mathrm{L}\left(\mathrm{L}=\mathrm{PPh}_{3}: \mathrm{R}=\mathrm{CH}_{2} \mathrm{CF}_{3}(2 \mathrm{a}), \mathrm{CH}\left(\mathrm{CF}_{3}\right)_{2}(2 \mathrm{~b})\right.$. Gold(I) complexes show higher catalytic activity than gold(III). In the catalytic system, the catalysts exist as the $\mathrm{C}$-bonded gold enolate complexes $\mathrm{Au}(\mathrm{I})(\mathrm{CH}(\mathrm{X})(\mathrm{Y}))(\mathrm{L})$ or $\mathrm{Au}(\mathrm{III}) \mathrm{Me}_{2}(\mathrm{CH}(\mathrm{X})(\mathrm{X}))(\mathrm{L})$, which can be isolated independently from the reactions of gold alkoxides with the corresponding active methylene compounds. The catalytic activity of the gold alkoxides is generally higher than that of isolated C-bonded gold enolates. The reaction rate increases with increase in the concentrations of catalyst and benzaldehyde, but is independent of the concentration of alkyl cyanoacetate. A reaction mechanism involving two catalytic pathways has been proposed.
\end{abstract}

Since gold is the most chemically inert metal, gold compounds are generally believed to have low reactivity. To date only a few examples of reactions catalysed by gold(I) and gold(III) have been reported (1), in spite of the fact that gold is usually considered a member of the group of transition metals which are used as effective catalysts in important chemical transformations. Amongst gold compounds, gold alkoxides are known to be very unstable because of substantial repulsion between filled $p \pi$ and $d \pi$ electrons (2). However, we have recently reported the isolation of gold(I) and gold(III) alkoxides having a tertiary phosphine ligand using reactions represented by Equations 1 and 2 (3):

$\mathrm{AuCIL}+\mathrm{KOR} \longrightarrow \mathrm{Au}(\mathrm{OR}) \mathrm{L}+\mathrm{KCI}$

$\mathrm{L}=\mathrm{PPh}_{3}: \mathrm{R}=\mathrm{CH}_{2} \mathrm{CF}_{3}(1 \mathrm{a}), \mathrm{CH}\left(\mathrm{CF}_{3}\right)_{2}(1 \mathrm{~b}) ;$

$\mathrm{L}=\mathrm{PCy}_{3}: \mathrm{R}=\mathrm{CH}_{2} \mathrm{CF}_{3}(1 \mathrm{c}), \mathrm{CH}\left(\mathrm{CF}_{3}\right)_{2}(1 \mathrm{~d})$

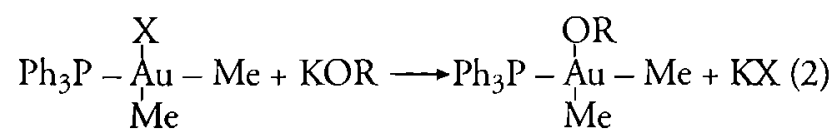

$\mathrm{R}=\mathrm{CH}_{2} \mathrm{CF}_{3}(2 \mathrm{a}), \mathrm{CH}\left(\mathrm{CF}_{3}\right)_{2}(2 \mathrm{~b})$

$\mathrm{X}=\mathrm{I}, \mathrm{NO}_{3}$
These products are highly basic and nucleophilic, and will abstract a proton from various organic substances such as alkyl cyanoesters and acetone to give the corresponding very stable and isolable $\alpha$-carbonyl organogold compounds $(3,4)$. These compounds are possible intermediates in catalytic condensation reactions of the Knoevenagel type, since they react with benzaldehyde to induce stoichiometric selective carbon-carbon bond formation. In this paper we report catalytic reactions of this type between alkyl cyanoacetates and benzaldehyde, which are promoted by gold alkoxides. It is emphasized that reports of homogeneous catalysis promoted by gold species are very rare, in spite of the intrinsic catalytic activity of gold and its compounds, although a gold(I) complex has been used to catalyse a similar condensation reaction involving coordination of an isocyanate group, where the gold acts as a template (5).

\section{RESULTS AND DISCUSSION}

Ethyl cyanoacetate smoothly reacted with benzaldehyde in benzene to give $(E)$-ethyl 2-cyano-3phenyl-2-propenoate in the presence of a catalytic amount of a gold alkoxide such as $\mathrm{Au}(\mathrm{OR}) \mathrm{L}(\mathrm{L}=$ $\mathrm{PPh}_{3}: \mathrm{R}=\mathrm{CH}_{2} \mathrm{CF}_{3}(\mathbf{1 a}), \mathrm{CH}\left(\mathrm{CF}_{3}\right)_{2}(\mathbf{1 b}) ; \mathrm{L}=\mathrm{PCy}_{3}: \mathrm{R}$ 
$=\mathrm{CH}_{2} \mathrm{CF}_{3}(\mathbf{1 c}), \mathrm{CH}\left(\mathrm{CF}_{3}\right)_{2}(\mathbf{1 d})$ or $\mathrm{AuMe}_{2}(\mathrm{OR}) \mathrm{L}(\mathrm{L}=$ $\left.\mathrm{PPh}_{3}: \mathrm{R}=\mathrm{CH}_{2} \mathrm{CF}_{3}(\mathbf{2 a}), \mathrm{CH}\left(\mathrm{CF}_{3}\right)_{2}(\mathbf{2 b})\right)$ at $50^{\circ} \mathrm{C}$ (Equation 3). Other active methylene compounds such as methyl cyanoacetate, malononitrile and acetophenone also reacted with benzaldehyde to give corresponding propenoates:

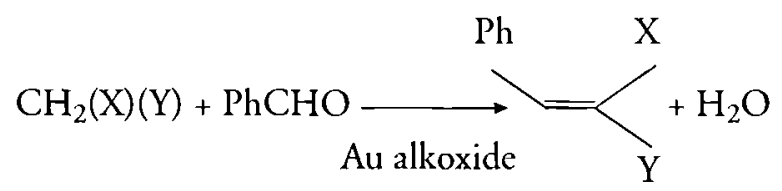

$\mathrm{X}=\mathrm{CN} ; \mathrm{Y}=\mathrm{COOMe}, \mathrm{COOEt}$

$\mathrm{X}=\mathrm{H} ; \mathrm{Y}=\mathrm{COPh}$

$\mathrm{X}=\mathrm{CN} ; \mathrm{Y}=\mathrm{CN}$

Results obtained under various reaction conditions are summarized in Table 1. The catalytic activity of the monovalent gold alkoxides is higher than that of the trivalent species. Substitution of the triphenylphosphine ligand in $\mathbf{1}$ and $\mathbf{2}$ with tricyclohexylphosphine had little effect on the catalytic activity. On the other hand, the more electron-withdrawing hexafluroisopropoxide showed higher catalytic activity than the trifluoroethoxide. Thus $1 \mathrm{a}$ and $\mathbf{1 c}$ catalysed the reactions of ethyl cyanoacetate, malononitrile and acetophenone, whereas $\mathbf{1 b}$ and $\mathbf{1 d}$ promoted the reactions of only ethyl cyanoacetate and malononitrile. The larger the pKa values of the active methylene compounds, the more easily will the condensation reaction proceed. These trends are similar to those of the gold alkoxides with the active methylene compounds to give organogold complexes (equations 4 and 5$)^{*}$ :

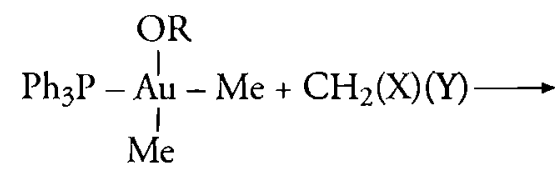

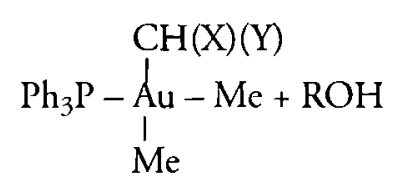

$\mathrm{Au}(\mathrm{OR}) \mathrm{L}+\mathrm{CH}_{2}(\mathrm{X})(\mathrm{Y}) \rightarrow \mathrm{Au}(\mathrm{CH}(\mathrm{X})(\mathrm{Y})) \mathrm{L}+\mathrm{ROH}(5)$

Catalytic Knoevenagel condensation reactions were observed between benzaldehyde and all the active methylene compounds, which reacted smoothly with gold alkoxides to give the corresponding organogold complexes. Thus, all the gold alkoxides reacted with ethyl cyanoacetate and malononitrile giving C-bonded enolate complexes, and also catalysed the corresponding condensation reactions. On the other hand, the deprotonation reactions of acetophenone by $\mathbf{l c}$ and $\mathbf{1 d}$ were very slow, and no reactions take place with $\mathbf{2} \mathbf{a}$ and $\mathbf{2 b}$, and these gold alkoxides were inactive for the condensation reactions. However, $\mathbf{1 a}$ and $\mathbf{1 b}$ are active catalysts for these reactions, since they smoothly give benzoylmethylgold complexes on reaction with acetophenone. All the corresponding Cbonded gold enolates were also found to be active catalysts for the condensation reactions (7).

In order to obtain further mechanistic insight into the reaction, time/yield curves were plotted for the formation of $(E)$-ethyl 2-cyano-3-phenyl-2-propenoate

Table 1 Gold catalysed condensation reactions with benzaldehyde

\section{Yield of condensation products $\mathrm{b} / \%$}

Catalyst

$\mathrm{Au}\left(\mathrm{OCH}_{2} \mathrm{CF}_{3}\right)\left(\mathrm{PPh}_{3}\right)$, la

$\mathrm{Au}\left(\mathrm{OCH}\left(\mathrm{CF}_{3}\right)_{2}\right)\left(\mathrm{PPh}_{3}\right), \mathrm{Ib}$

$\mathrm{Au}\left(\mathrm{OCH}_{2} \mathrm{CF}_{3}\right)\left(\mathrm{PCy}_{3}\right)$, Ic

$\mathrm{Au}\left(\mathrm{OCH}\left(\mathrm{CF}_{3}\right)_{2}\right)\left(\mathrm{PCy}_{3}\right)$, Id

$\mathrm{AuMe}_{2}\left(\mathrm{OCH}_{2} \mathrm{CF}_{3}\right)\left(\mathrm{PPh}_{3}\right), 2 \mathrm{a}^{\mathrm{c}}$

$\mathrm{AuMe}_{2}\left(\mathrm{OCH}\left(\mathrm{CF}_{3}\right)_{2}\right)\left(\mathrm{PPh}_{3}\right), 2 b^{d}$

\section{$\mathrm{NCCH}_{1} \mathrm{COOEt}$}

93

82

89

81

38

87

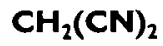

40

37

54

43

57

58
MeCOPh

40

0

66

0

0

0

${ }^{\prime C}$ Catalyst, 10 mol\%; [Active methylene compound], $0.38 \mathrm{M}$; [Benzaldehyde], $0.33 \mathrm{M}$; Reaction time, $97 \mathrm{~h}$ in $\mathrm{C}_{6} \mathrm{D}_{6}$ at $50^{\circ} \mathrm{C}$.

${ }^{b}$ Determined by ' $\mathrm{H} \mathrm{NMR}, \mathrm{E}-\mathrm{PhCH}=\mathrm{C}(\mathrm{CN}) \mathrm{COOEt}$ for $\mathrm{NCCH}_{2} \mathrm{COOEt}, \mathrm{PhCH}=\mathrm{C}(\mathrm{CN})_{2}$ for $\mathrm{CH}_{2}(\mathrm{CN})_{2}, \mathrm{E}-\mathrm{PhCH}=\mathrm{CHCOPh}$ for MeCOPh; ${ }^{c}$ Catalyst, 20 mol\%; Reaction time, 25 h in $C_{6} D_{6}$ at $50^{\circ} \mathrm{C}$. 
from ethyl cyanoacetate and benzaldehyde monitored by gas liquid chromatography (GLC). It can be concluded from the results plotted in Figure 1 that the gold(I) alkoxide $\mathbf{1 b}$ produces a faster reaction rate than the gold(III) alkoxide $\mathbf{2 b}$. When the catalyst concentration was increased from 10 to $30 \mathrm{~mol} \%$, the rate of the reaction also increased by a factor of ca 3 (Figure 2). The apparent reaction rate also increased with increase in the concentration of benzaldehyde (Figure 3), but was relatively insensitive to the concentration of ethyl cyanoacetate (Figure 4). It should be noted that the reaction rates in the presence of gold alkoxide catalysts were higher than those obtained in the presence of the corresponding Cbonded enolates prepared by the deprotonation of active methylene compounds by the gold alkoxides (Figures 5 and 6). However, when one equivalent of the alcohol was added to the C-bonded enolate reaction system, the catalytic activity was restored to the same level as for the corresponding gold alkoxide. Addition of increased amounts of the free alcohol had little effect on the reaction rate'.

In Figure 7 it can be seen that the reaction rate increased with the increasing polarity of the solvent, suggesting a polar transition state for the reaction. In order to identify the gold species in the catalysed reaction system, ${ }^{1} \mathrm{H}$ NMR was used with catalyst $\mathbf{1 b}$, using $\mathrm{C}_{6} \mathrm{D}_{6}$ as solvent. The only gold species observed was the $\mathrm{C}$-bonded enolate.

On the basis of the results obtained, the two-

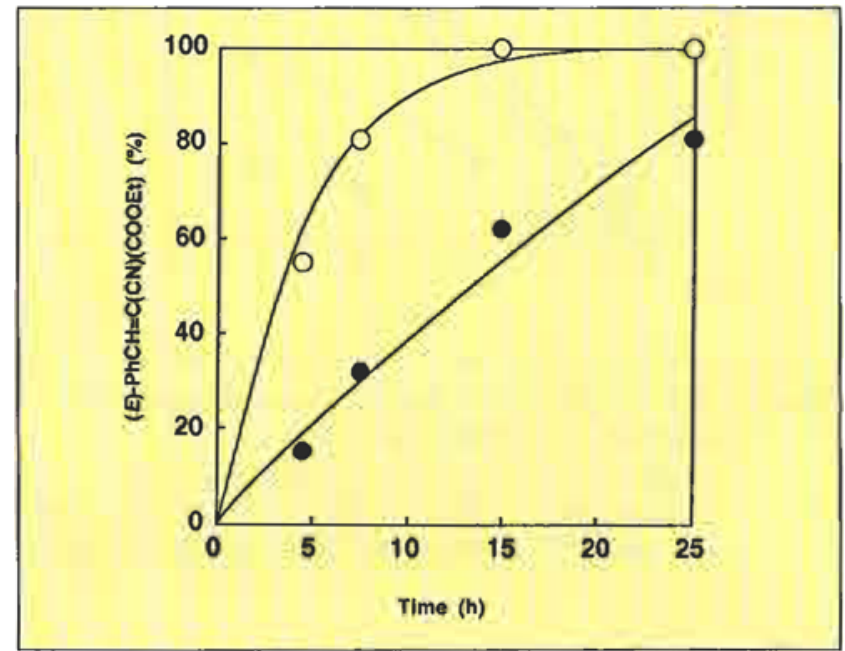

Figure 1 Time-yield curves for the reaction of ethyl cyanoacetate with benzaldehyde catalysed by gold (I) and (III) alkoxides. Conditions in $C_{6} D_{6}$ at $50^{\circ} \mathrm{C}$. Catalyst: $\mathrm{Au}\left(\mathrm{OCH}\left(\mathrm{CF}_{3}\right)_{2}\right)\left(\mathrm{PPh}_{3}\right)(\mathbf{l b})=20 \mathrm{~mol} \%$ (O), $\mathrm{AuMe}_{2}\left(\mathrm{OCH}\left(\mathrm{CF}_{3}\right)_{2}\right)(\mathbf{2 b})=20 \mathrm{~mol} \%$ (৫); $\left[\mathrm{CH}_{2}(\mathrm{CN}) \mathrm{COOEt}\right]=0.38 \mathrm{M} ; \mathrm{PhCHO}=0.33 \mathrm{M}$.

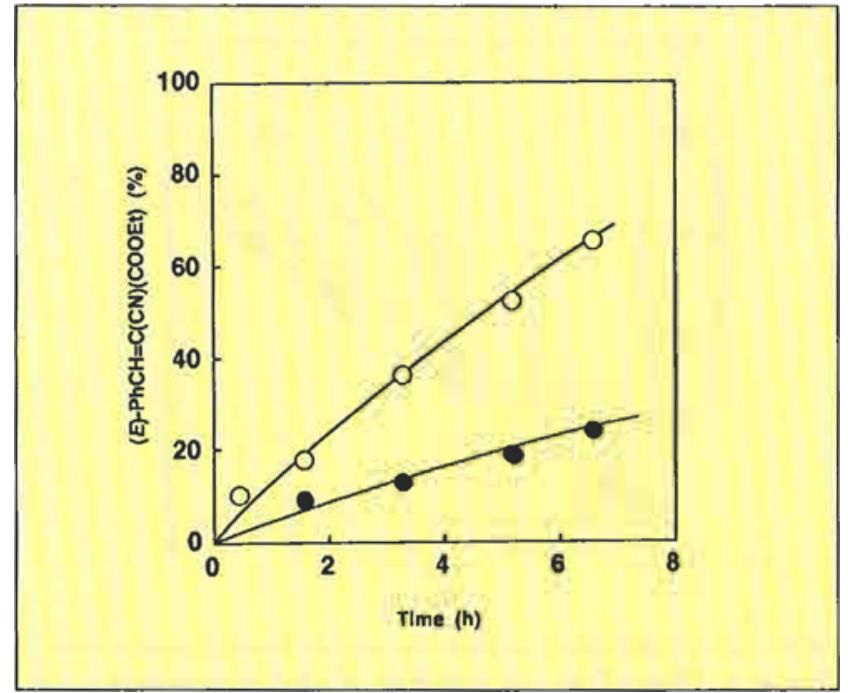

Figure 2 Effect of the concentration of gold alkoxide $2 \boldsymbol{b}$ on the catalytic reaction. Conditions: in DMSO at $50^{\circ} \mathrm{C}$.

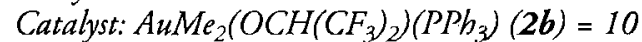
mol\% (०), 30 mol\% (O); $\left[\mathrm{CH}_{2}(\mathrm{CN}) \mathrm{COOEt}\right]=$ $0.15 \mathrm{M} ; \mathrm{PhCHO}=0.10 \mathrm{M}$.

pathway mechanism depicted in Scheme 1 is proposed ${ }^{\ddagger}$. Firstly, the gold alkoxide reacts with the active methylene compound to abstract a proton and give a C-bonded enolate, accompanied by the liberation of the alcohol. The C-bonded enolate is the thermodynamically most stable species. Then the Cbonded enolate reacts with benzaldehyde to give the corresponding gold alkoxide, which then reacts with a

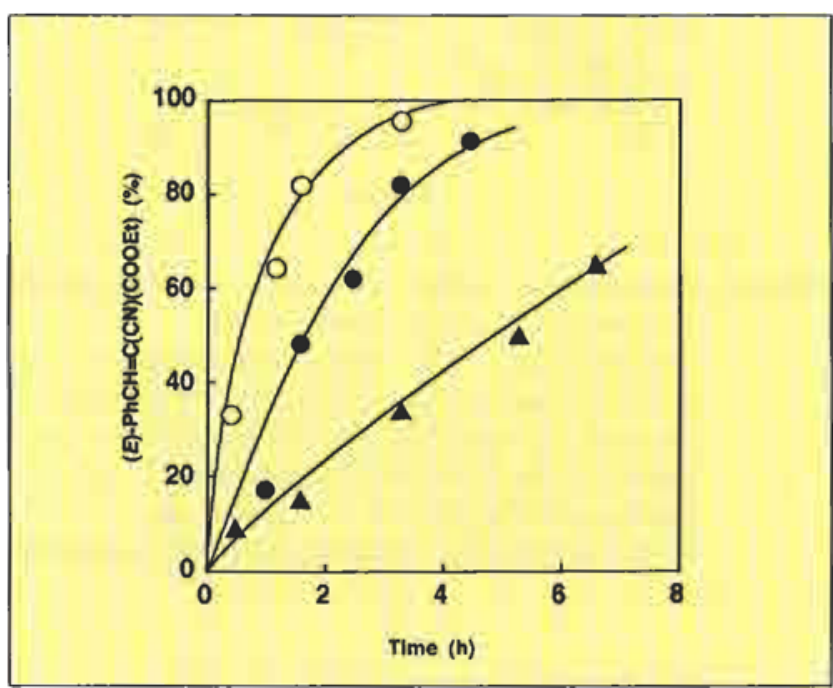

Figure 3 Effect of the concentration of benzaldehyde on the catalytic reaction. Conditions: in DMSO at $50^{\circ} \mathrm{C}$.

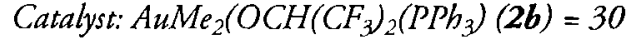
mol\%; $\left[\mathrm{CH}_{2}(\mathrm{CN}) \mathrm{COOEt}\right]=0.15 \mathrm{M} ;[\mathrm{PhCHO}]=$ $0.10 M(\Lambda), 0.44 M(\bullet), 0.71 M(0)$. 


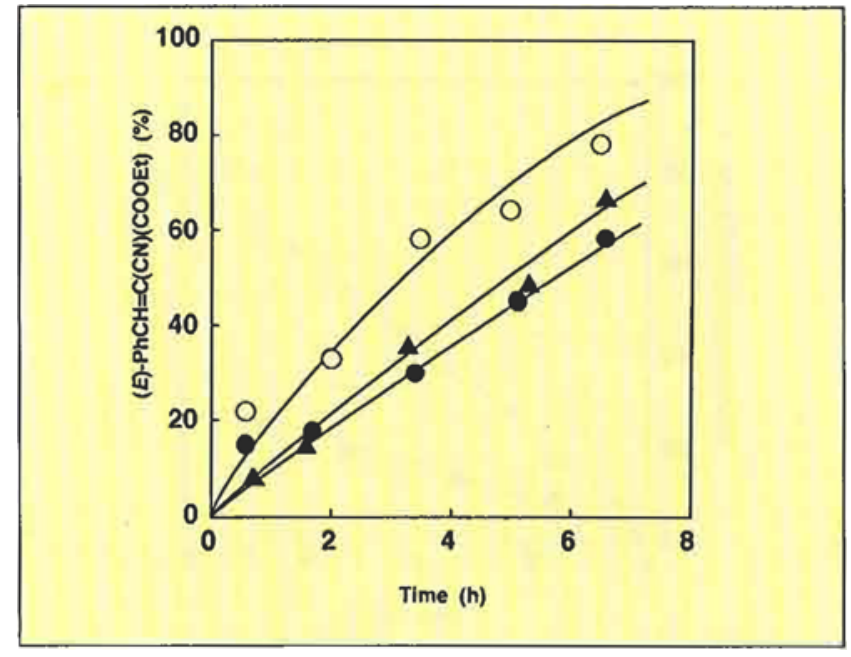

Figure 4 Effect of the concentration of ethyl cyanoacetate on the catalytic reaction. Conditions: in DMSO at $50^{\circ} \mathrm{C}$.

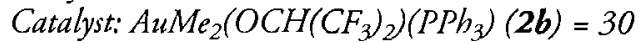
mol\%; $\left[\mathrm{CH}_{2}(\mathrm{CN}) \mathrm{COOEt}\right]=0.15 \mathrm{M}(\mathbf{\Delta}), 0.30 \mathrm{M}$

(๑), $0.94 \mathrm{M}(\mathrm{O}) ;[\mathrm{PhCHO}]=0.10 \mathrm{M}$.

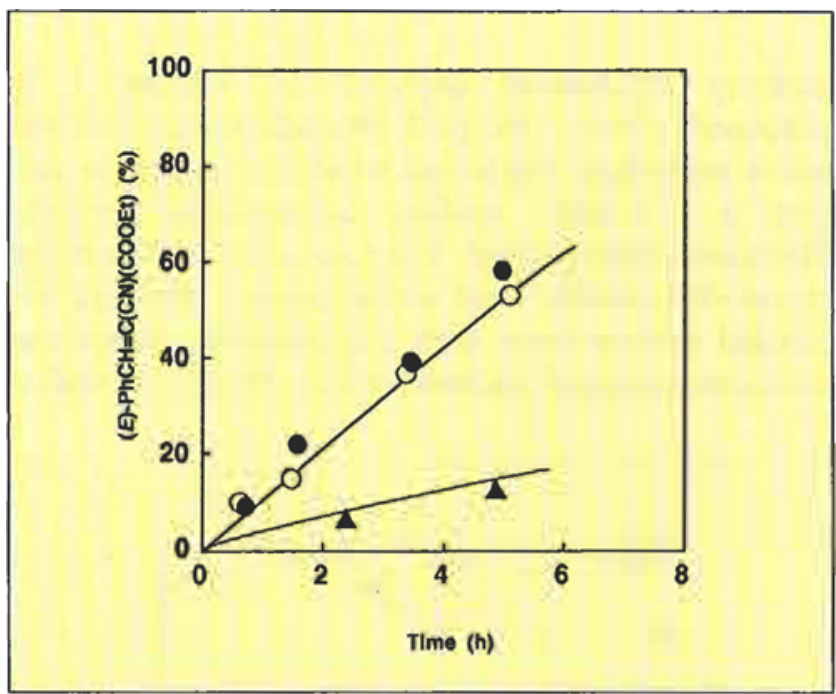

Figure 5 Comparison of catalytic reactions promoted by gold(I) and alkoxide $\mathbf{I b}$ and $C$-bonded enolate

$\mathrm{Au}(\mathrm{CH}(\mathrm{CN})(\mathrm{COOEt}))\left(\mathrm{PPh}_{3}\right)$. Conditions: in $\mathrm{C}_{6} \mathrm{D}_{6}$ at $50^{\circ} \mathrm{C}$. Catalyst: $\mathrm{Au}\left(\mathrm{OCH}\left(\mathrm{CF}_{3}\right)_{2}\right)\left(\mathrm{PPh}_{3}\right)(\mathbf{I b})=$ $20 \mathrm{~mol}^{\circ}$ (O), $\mathrm{Au}\left(\mathrm{CH}(\mathrm{CN})(\mathrm{COOEt})\left(\mathrm{PPh}_{3}\right)=20\right.$ mol\% (ム), $\left.\mathrm{Au}(\mathrm{CH}(\mathrm{CN})(\mathrm{COOEt}))(\mathrm{PPh})_{3}\right)=20$ mol\% and $\left(\mathrm{CF}_{3}\right)_{2} \mathrm{CHOH}=20 \mathrm{~mol} \%$ (৫), $\left[\mathrm{CH}_{2}(\mathrm{CN}) \mathrm{COOEt}\right]=0.38 \mathrm{M} ;[\mathrm{PhCHO}]=0.33 \mathrm{M}$.

further molecule of active methylene compound to close the catalytic cycle (Path A). Similar intermediates have been proposed in rhodium catalysed reactions $(8)$. The final step includes dehydration to give the $E$ isomer selectively (9).

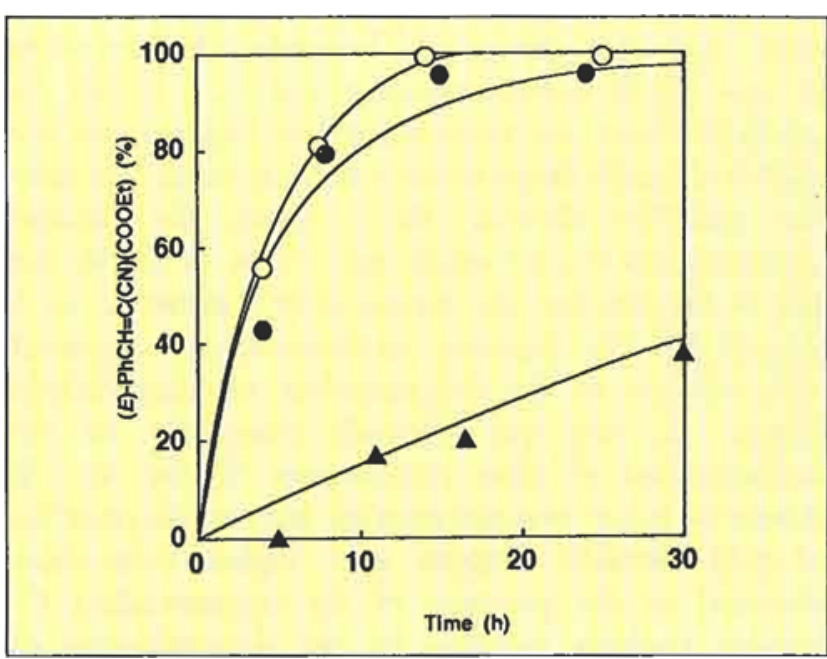

Figure 6 Comparison of catalytic reactions promoted by gold(I) alkoxide $\mathbf{2 b}$ and $C$-bonded enolate $\mathrm{AuMe}_{2}(\mathrm{CH}(\mathrm{CN})(\mathrm{COOEt}))\left(\mathrm{PPh}_{3}\right)$. Conditions: in DMSO at $50^{\circ} \mathrm{C}$. Catalyst: $\mathrm{AuMe}_{2}\left(\mathrm{OCH}\left(\mathrm{CF}_{3}\right)_{2}\right)$ $\left(\mathrm{PPh}_{3}\right)(\mathbf{2 b})=30$ mol\% (o), $\mathrm{AuMe}_{2}$ $\left(\mathrm{CH}(\mathrm{CN})(\mathrm{COOEt})\left(\mathrm{PPh}_{3}\right)=30 \mathrm{~mol} \%\right.$ (ム), $\mathrm{AuMe}_{2}$ $\left(\mathrm{CH}(\mathrm{CN})(\mathrm{COOEt})\left(\mathrm{PPh}_{3}\right)=30 \mathrm{~mol} \%\right.$ and $\left(\mathrm{CF}_{3}\right)_{2} \mathrm{CHOH}=30 \mathrm{~mol} \%(\bullet)$;

$\left[\mathrm{CH}_{2}(\mathrm{CN})(\mathrm{COOEt})\right]=0.15 \mathrm{M} ;[\mathrm{PhCHO}]=0.10 \mathrm{M}$.

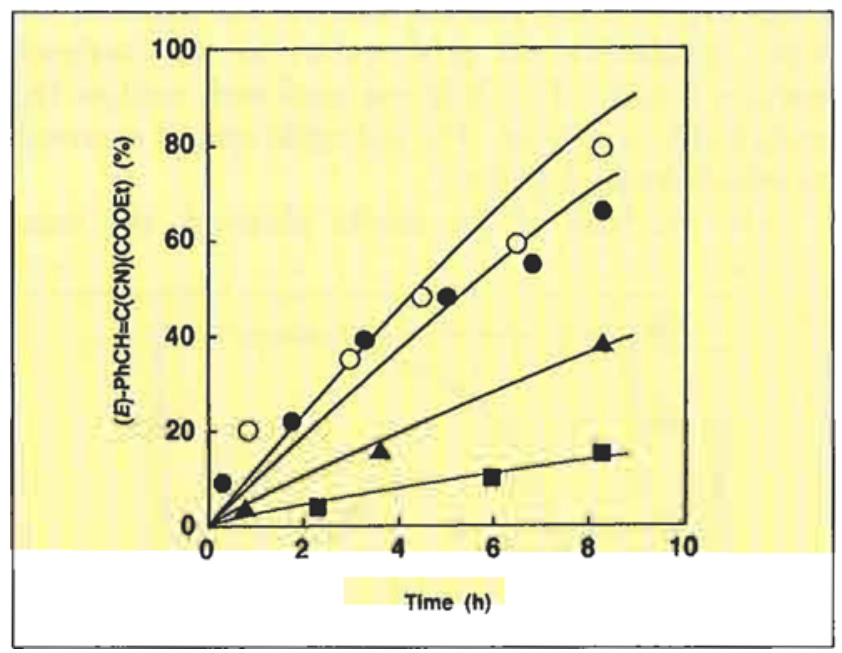

Figure 7 Solvent effect on the reaction catalysed by gold(III) alkoxide. Conditions: at $50^{\circ} \mathrm{C}$. $\mathrm{AuMe}_{2}\left(\mathrm{OCH}\left(\mathrm{CF}_{3}\right)_{2}\right)\left(\mathrm{PPh}_{3}\right)(\mathbf{2 b})=30 \mathrm{~mol} \%$ $\left[\mathrm{CH}_{2}(\mathrm{CN})(\mathrm{COOEt})\right]=0.15 \mathrm{M} ;[\mathrm{PhCHO}]=0.10$

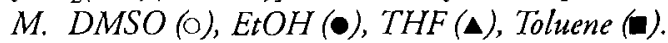

When the free alcohol is present, the reaction may proceed via the low energy reaction Path $B$. The oxygen-containing intermediate (aldolato gold species) quickly reacts with the alcohol giving the product plus the gold alkoxide., promoted by hydrogen bonding 


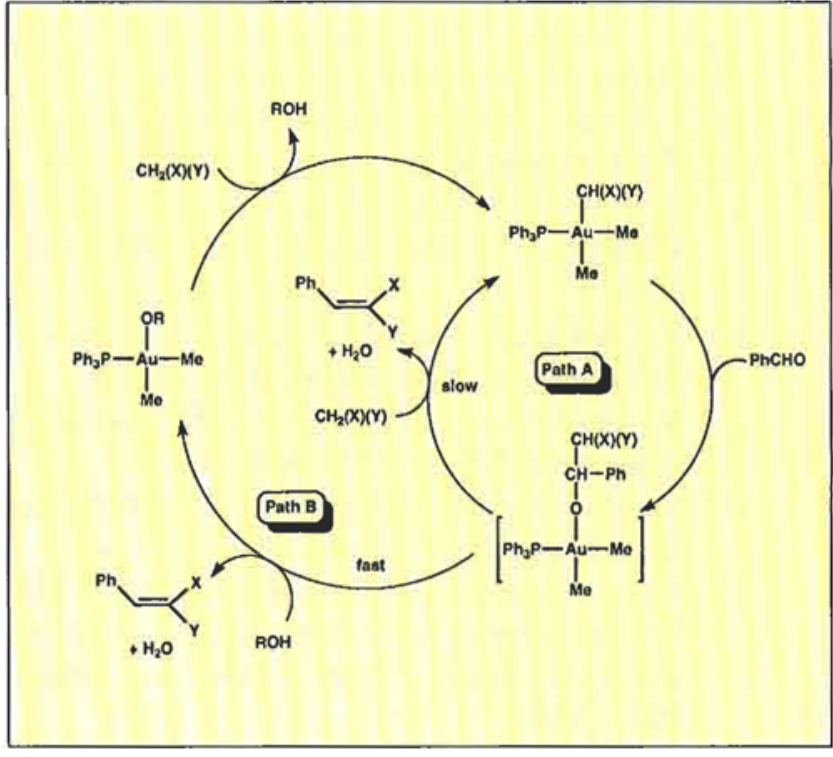

Scheme 1 A proposed mechanism of catalytic Knoevenagd reaction promoted by gold alkoxide.

between the oxygen atom of the gold alkoxide intermediate and the $\mathrm{OH}$ of the alcohol. This type of hydrogen bonding interaction has been recently identified in platinum, palladium and gold alkoxides (9). The large solvent effects observed are consistent with the proton abstraction process being highly polarized.

\section{EXPERIMENTAL}

All the manipulations were carried out under nitrogen or argon using standard Schlenk techniques. Solvents were dried by usual methods and were kept under nitrogen before use. Reagents were purchased, dried with $\mathrm{MgSO}_{4}$ and distilled under nitrogen. Gold alkoxides were prepared according to the method of our previous paper (3). ${ }^{1} \mathrm{H}$ NMR spectra were measured by JEOL FX200 and LA300 spectrometers. The organic products in the catalytic reactions were analysed by GLC using Shimadzu GC 6A. GCMS spectra were recorded by Shimadzu QP-2000 spectrometer at $70 \mathrm{eV}$.

\section{Catalytic reactions of ethyl cyanoacetate with benzaldehyde}

A standard amount of gold compound was placed in a Schlenk tube with a septum rubber cap. A DMSO solution $(3.0 \mathrm{ml})$ of benzaldehyde $(0.200 \mathrm{mmol})$ containing biphenyl $(0.0080 \mathrm{ml})$ as an internal standard was added at room temperature. Then the active methylene compound $(0.250 \mathrm{mmol})$ was added by a hypodermic syringe through the septum to start the reaction. The flask was placed in a thermostatted oil bath at $50 \pm 1^{\circ} \mathrm{C}$. The yields of the products and conversion were periodically estimated by GLC. ${ }^{1} \mathrm{H}$ NMR samples containing standard amounts of $\mathrm{Au}$ compound, benzaldehyde, ethyl cyanoacetate and dioxane $(1.00 \mu \mathrm{l})$ as an internal standard in $\mathrm{C}_{6} \mathrm{D}_{6}(300$ $\mu \mathrm{l})$ were prepared under nitrogen, and the temperature of the NMR sample was kept constant as above. The yield of the product was estimated periodically by ${ }^{1} \mathrm{H}$ NMR integration. Other reactions were performed analogously. In other solvents $(1.00 \mathrm{ml})$, the yields were estimated by GLC using an internal standard of biphenyl $(0.100 \mathrm{mmol})$. Products were periodically determined and characterized using NMR and/or GCMS: $(E)-\mathrm{PhCH}=\mathrm{C}(\mathrm{CN})(\mathrm{COOE} \mathrm{t}): \mathrm{m} / \mathrm{z}=201\left(\mathrm{M}^{+}\right)$, $172\left(\mathrm{M}^{+}-\mathrm{Et}\right), 156\left(\mathrm{M}^{+}-\mathrm{OEt}\right), 128\left(\mathrm{M}^{+}-\mathrm{COOEt}\right), 102$ $\left(\mathrm{PhCH}=\mathrm{C}^{+}\right), 77\left(\mathrm{Ph}^{+}\right) ;{ }^{1} \mathrm{H}$ NMR $\left(\mathrm{C}_{6} \mathrm{D}_{6}\right): 81.00$ $\left(\mathrm{CH}_{2} \mathrm{CH}_{3}, \mathrm{t}, \mathrm{J}=7.1 \mathrm{~Hz}, 3 \mathrm{H}\right), 4.00\left(\mathrm{CH}_{2} \mathrm{CH}_{3}, \mathrm{q}, \mathrm{J}=\right.$ $7.1 \mathrm{~Hz}, 2 \mathrm{H}), 8.04(\mathrm{CH}=, \mathrm{s}, 1 \mathrm{H}), 7.0-7.7(\mathrm{Ph}, \mathrm{m}, 5 \mathrm{H})$ $8.04(\mathrm{CH}=, s, \mathrm{IH}) . \quad \mathrm{PhCH}=\mathrm{C}(\mathrm{CN})_{2}: \mathrm{m} / \mathrm{z}=154\left(\mathrm{M}^{+}\right)$, $127\left(\mathrm{PhC}=\mathrm{CN}^{+}\right), 103\left(\mathrm{PhCH}=\mathrm{CH}^{+}\right), 77\left(\mathrm{Ph}^{+}\right) ;{ }^{1} \mathrm{H}$ $\operatorname{NMR}\left(\mathrm{C}_{6} \mathrm{D}_{6}\right): 8.04(\mathrm{CH}=, \mathrm{s}, \mathrm{IH}), 88.04\left(\mathrm{CH}=, \mathrm{s},{ }^{1} \mathrm{H}\right)$, 7.0-7.7 (Ph, $\mathrm{m}, 5 \mathrm{H}),(E)-\mathrm{Ph} \mathrm{CH}=\mathrm{CH}(\mathrm{COPh}): \mathrm{m} / \mathrm{z}=$ $207\left(\mathrm{M}^{+}\right), 131\left(\mathrm{M}^{+}-\mathrm{Ph}\right), 103\left(\mathrm{PhCH}=\mathrm{CH}^{+}\right), 77\left(\mathrm{Ph}^{+}\right)$.

\section{CONCLUSIONS}

It is noteworthy that these gold-catalysed Knoevenagel reactions can be carried out under neutral and mild conditions, where the catalytic activity and selectivity of the reaction may be controlled by changing the properties of the alkoxides, ligands and the valency of the metal. These factors are in sharp contrast to the selective Murahashi aldol and Michael reactions catalysed by ruthenium, where coordination of the cyano group giving a zwitterionic intermediate constitutes the key step in the catalysis (10). Now that this example of homogeneous gold catalysis has been identified, we are prompted to look for other examples where gold species catalyse reactions in solution.

\section{ABOUT THE AUTHORS}

Professor Sanshiro Komiya has worked in the Department of Applied Chemistry at Tokyo University of Agriculture and Technology since 1989 and studies the organometallic chemistry of transition metals, including gold. Drs Atsushi Fukuoka and Masafumi Hirano are members of Professor Sanshiro's research group. Takuo Sone and Yoko Usui are graduate students in the Department 


\section{REFERENCES}

1 a R.J. Puddephatt, 'Chemistry of Gold', Elsevier, Oxford, 1978

b G. Wilkinson, F.G.A. Stone and E.W. Abel, eds., 'Comprehensive Organometallic Chemistry', Pergamon Press, Oxford, 1982

c E.W. Abel, F.G.A. Stone and G. Wilkinson, Comprehensive Organometallic Chemistry II, Pergamon Press, Oxford, 1995

d M. Haruta, T. Kobayashi, H. Sano and N. Yamada, Chem. Lett., 1987, 405

e J. Schwank, Gold Bull., 1983, 16, 98; 1985 18,2

f I.E. Wachs, Gold Bull., 1983, 16, 98

g G.C. Bond, Gold Bull., 1972, 5, 11

h M. Haruta, Shokubai, 1996, 38, 196

2 For example:

a H.E. Bryndza and W. Tam, Chem. Rev., $1988,88,1163$

b K.G. Caulton and L.G. Hubert-Pfalzgraf, Chem. Rev., 1990, 90, 969

c R.C. Merhotra, A. Singh and U.M. Tripathi, Chem. Rev., 1991, 91, 1287

d R.C. Merhotra, S.K. Agarwal and Y.P. Singh, Coord Chem. Rev, 1985, 68, 101

e R.C. Merhotra, Adv. Inorg. Chem. Radiochem., 1983, 26, 269

3 a T. Sone, M. Iwata, N. Kasuga and S. Komiya, Chem. Lett., 1991, 1949

b S. Komiya, M. Iwata, T. Stone and A. Fukuoka, J. Chem. Soc., Chem. Commun., 1992, 1109

4 T. Sone and S. Komiya, unpublished results

5 a Y. Ito, M. Sawamura and T. Hayashi, J. Am. Chem. Soc., 1986, 108, 6405

b Y. Ito, M. Sawamura and T. Hayashi, Tetrahedron Lett., 1987, 28, 6215; 1988, 29, 6321; 1989, 30, 4861

c V.A. Solochonok and T. Hayashi, Tetrabedron Lett., 1994, 35, 2713

6 a J.J. Doney, R.G. Bergman and C.H. Heathcock, J. Am. Chem. Soc., 1985, 107, 3724

b C.H. Heathcock, J.J. Doney and R.G. Bergman, Pure and Appl. Chem., 1985, 57, 1789

c E.R. Burkhardt, J.J. Doney, R.G. Bergman and C.H. Heathoock, J. Am. Chem. Soc., I987, 109, 2022

d E.R. Burkhardt, J.J. Doney, J.G. Stack, C.H. Heathcock and R.G. Bergman, J. Mol. Cat., $1987,41,41$
7 G.A. Slough, R.G. Bergman and C.H. Heathcock, J. Am. Chem. Soc., 1989, 111, 938

8 H.O. House, 'Modern Synthetic Reactions', 2nd Ed., W.A. Benjamin Inc., London, 1972, p.635

9 a Y. Kim, K. Osakada, A. Takenaka and A. Yamamoto, J. Am. Chem. Soc., 1990, 112, 1096

b K. Osakada, Y. Kim, M. Tanaka, S. Ishuro and A. Yamamoto, Inorg. Chem. 1991, 30, 197

c K. Osakada, Y. Kim and A. Yamamoto, J. Organomet. Chem. 1990, 382, 303

d K. Osakada, K. Oshiro and A. Yamamoto, Organometallics, 1991, 10, 404

e S.E. Kegley, C.J. Schaverien, J.H. Freudenberger, R.G. Bergman, S.P. Nolan and C.D. Hoff, J. Am. Chem. Soc., 1987, 109, 6536

$f$ C.D. Bugno, M. Pasquali, P. Leoni, S. Sabatino and D. Braga, Inorg. Chem., 1989, 28, 1390

10 a S.-I. Murahashi, T. Naota, H. Taki, M. Mizuno, H. Takaya, S. Komiya, Y. Mizuho, N. Oyasato, M. Hiraoka, M. Hirano and A. Fukuoka, J. Am. Chem. Soc., 1995, 117, 12436 and references cited therein

b E. Gomez-Bengoa, J.M. Cuerva, C. Mateo and A.M. Echavarren, J. Am. Chem. Soc., $1996,118,8553$

\footnotetext{
* The rate of the reactions between the alkoxides and the active methylene compounds increases on decreasing the $\mathrm{pH}$ values of the active methylene compounds. On the other hand, the kinetic and thermodynamic stabilities of the gold alkoxides also increase when the steric bulkiness increases as well as when the phosphine ligand is more electron-donating, and a 4-centre transition state involving gold has been proposed for reactions of gold alkoxides with active methylene compounds: see reference 3 and T. Sone and S. Komiya, unpublished results.

$\dagger$ It is not clear at present why the addition of excess alcohol had little effect on rate. However, a small amount of alcohol may be enough to shift the equilibrium to the gold alkoxide. The addition of strong acid, such as $\mathrm{HCl}$, killed the catalytic activity completely, since this gave catalytically inactive gold chloride.

$\ddagger$ In response to a referee's comment, we would like to state that the catalysis is promoted by a C-bonded enolate in the absence of alkoxide, and both the ligands and the metal valence influence the reactions. We therefore conclude that the reaction is catalysed by gold species rather than free base.
} 